\title{
Transport of North African dust from the Bodélé depression to the Amazon Basin: a case study
}

\author{
Y. Ben-Ami ${ }^{1}$, I. Koren ${ }^{1}$, Y. Rudich ${ }^{1}$, P. Artaxo ${ }^{2}$, S. T. Martin ${ }^{3}$, and M. O. Andreae ${ }^{4}$ \\ ${ }^{1}$ Department of Environmental Sciences and Energy Research, Weizmann Institute of Science, Rehovot, Israel \\ ${ }^{2}$ Institute of Physics, University of São Paulo, Brazil \\ ${ }^{3}$ School of Engineering and Applied Sciences \& Department of Earth and Planetary Sciences, Harvard University, \\ Cambridge, Massachusetts, USA \\ ${ }^{4}$ Biogeochemistry Department, Max Planck Institute for Chemistry, Mainz, Germany
}

Received: 26 January 2010 - Published in Atmos. Chem. Phys. Discuss.: 12 February 2010

Revised: 23 July 2010 - Accepted: 26 July 2010 - Published: 16 August 2010

\begin{abstract}
Through long-range transport of dust, the NorthAfrican desert supplies essential minerals to the Amazon rain forest. Since North African dust reaches South America mostly during the Northern Hemisphere winter, the dust sources active during winter are the main contributors to the forest. Given that the Bodélé depression area in southwestern Chad is the main winter dust source, a close link is expected between the Bodélé emission patterns and volumes and the mineral supply flux to the Amazon.

Until now, the particular link between the Bodélé and the Amazon forest was based on sparse satellite measurements and modeling studies. In this study, we combine a detailed analysis of space-borne and ground data with reanalysis model data and surface measurements taken in the central Amazon during the Amazonian Aerosol Characterization Experiment (AMAZE-08) in order to explore the validity and the nature of the proposed link between the Bodélé depression and the Amazon forest.

This case study follows the dust events of 11-16 and 1827 February 2008, from the emission in the Bodéle over West Africa (most likely with contribution from other dust sources in the region) the crossing of the Atlantic Ocean, to the observed effects above the Amazon canopy about 10 days after the emission. The dust was lifted by surface winds stronger than $14 \mathrm{~m} \mathrm{~s}^{-1}$, usually starting early in the morning. The
\end{abstract}

Correspondence to: Y. Ben-Ami

(yuval.ben-ami@weizmann.ac.il) lofted dust, mixed with biomass burning aerosols over Nigeria, was transported over the Atlantic Ocean, and arrived over the South American continent. The top of the aerosol layer reached above $3 \mathrm{~km}$, and the bottom merged with the boundary layer. The arrival of the dusty air parcel over the Amazon forest increased the average concentration of aerosol crustal elements by an order of magnitude.

\section{Introduction}

Mineral dust has been suggested to play an important role in biogeochemical cycles (Falkowski et al., 1998; Garrison et al., 2003; Jickells et al., 2005, Mahowald et al., 2009), climatic processes (Twomey, 1974; Levin et al., 1996; Albrecht, 1989; Falkowski et al., 1998; Ramanathan et al., 2001; Rosenfeld et al., 2001; Koren et al., 2005; Kaufman et al., 2005c; Teller and Levin 2006; Jiang et al., 2006; Stith et al., 2009), and human life (Prospero, 1999; Griffin and Kellogg, 2004).

Despite major efforts, the spatial and temporal distributions of mineral dust remain uncertain. Therefore, the nature and magnitude of dust feedbacks on climatic processes, biogeochemical cycles, and human life are not well constrained. Important unanswered questions include: what are the exact North African dust sources of crustal elements observed in the Amazon Basin and what are their associated fluxes?

Published by Copernicus Publications on behalf of the European Geosciences Union. 
The Amazon rain forest has important roles in Earth's climate system. It acts as a source of primary and secondary biogenic aerosol particles and components (Artaxo and Hansson, 1994; Quéré et al., 2009; Martin et al., 2010). It also affects the global biogeochemical cycles, including carbon cycling (Davidson and Artaxo, 2004). To sustain the well-being of the forest and the fragile balance between the rain forest and the atmosphere, the Amazon forest must receive a sufficient amount of nutrients. However, the intense precipitation and ensuing floods wash most of the soluble minerals from the rainforest soil, leaving behind a quite infertile soil, with limited nutrients available for plants growth (Vitousek and Sanford, 1986). In-situ measurements (Talbot et al., 1990) and image analysis studies (Swap et al., 1992) have suggested that the deficiency of nutrients in the Amazon soil can be replenished by deposition of mineral dust, mostly from the Sahara.

Mineral dust aerosol were previously observed in the Amazon region, and its appearance was attributed to arrival of air parcels from North Africa (e.g.: Prospero et al., 1981; Artaxo et al., 1990; Swap et al., 1992; Formenti et al., 2001). Nevertheless, not all dust outbreaks reach the Amazon forest. Transport of the North African dust across the Atlantic Ocean was studied since the early seventies. The active dust sources, the trajectories across the Atlantic Ocean, as well as the sink of North African dust, are subjected to the seasonal cycle due to the shift in the location of the inter tropical convergence zone. During the late boreal winter and the spring, North African dust, mixed with biomass-burning aerosols from the Sahel region (Formenti et al., 2008; Ansmann et al., 2009), follows southern trajectories heading to the northern part of South America (Kaufmann et al., 2005a; Huang et al., 2010). The transport of dust over the Atlantic Ocean (about 7 days) was intensively studied by ground based (e.g.: Prospero et al., 1981, 1999) and airborne measurements (e.g.: Prospero and Carlson, 1972; Carlson and Prospero, 1972; Reid et al., 2002), satellite remote sensing (Karyampudi et al., 1999; Torres et al., 2002; Kaufman et al., 2005a; Liu et al., 2008a and b; Generoso et al., 2008; Ansmann et al., 2009; Ben-Ami et al., 2009; Huang et al., 2010) and transport models (e.g.: Ginoux et al., 2004; Schepanski et al., 2009; Engelstaedter et al., 2009).

The arrival of the dust to the Amazon forest is manifested by an increase of crustal elements such as $\mathrm{Al}, \mathrm{Si}, \mathrm{Fe}, \mathrm{Ti}$, and $\mathrm{Mn}$, generally from the submicron fraction (e.g.: Prospero et al., 1981; Artaxo et al., 1990; Swap et al., 1992; Formenti et al., 2001; Martin et al., 2010). The peak of crustal elements range from one to several days, and is typical to the months of March and April, which is the wet season in the central part of the Amazon Basin. Kaufmann et al. (2005a) estimated that $50 \pm 15 \mathrm{Tg} \mathrm{y}^{-1}$ of dust reaches the Amazon Basin. Transport of biomass smoke from Africa occurs also during the dry season (Martin et al., 2010). The above elements serve as markers for the arrival of mineral dust and they are not necessarily essential for plants growth. The bioavailabil- ity of elements contained in mineral dust to plants is beyond the scope of the paper.

Although the transport route of Saharan dust was extensively studied, the exact origin of the dust, as well as the magnitude and the frequency of transport are not well known. An important reason for these uncertainties is that previous studies focused either on the region of the Amazon forest and the transport route over the Atlantic Ocean, or over North Africa , and so the direct link, between the source and the sink locations was not studied in sufficient detail.

Koren et al. (2006) suggested that the Bodélé depression (centered in Chad, $17^{\circ} \mathrm{N} 18^{\circ} \mathrm{E}$ ), is the main source for the dust transported to the Amazon Basin. Using a year-long satellite data set, they studied the emission patterns of the Bodélé, and suggested a dust transport route towards the Amazon. However, their study did not include ground-based measurements, and their conclusions were based on inductive reasoning, showing that the North African dust arrives in the Amazon mostly during the (Northern Hemisphere) wintertime and that the Bodélé is the main winter source. Therefore, they concluded that the Bodélé contributes a significant amount of nutrients to the Amazon Basin.

Other regional (Schepanski et al., 2007; Ginoux et al., 2009) and global (e.g.: Prospero et al., 2002) remote sensing studies also identified the Bodélé depression as one of the most active dust sources. The Bodélé depression is characterized by a year-long activity and a dust emission peak during the Northern Hemisphere winter months, with estimated emissions of $(58 \pm 8) \times 10^{6}$ tonnes (estimated for winterspring of 2003-2004), equivalent to emissions of more than $7 \times 10^{5}$ tonnes per emission day (Koren et al., 2006). The uniqueness of the Bodélé as a prime dust source was attributed to three factors: A. Mineralogy - being part of the former lake Mega-Chad, the Bodélé $\left(\sim 133532 \mathrm{~km}^{2}\right)$ is a rich dust reservoir, including low density diatomite and eroded diatomite sand (Bristow et al., 2009), composed of $\mathrm{SiO}_{2}$ and small quantities of $\mathrm{Al}_{2} \mathrm{O}_{3}$ and $\mathrm{Fe}$ (Chappell et al., 2008). The importance of the Bodélé in fertilizing the Amazon Basin with Fe and P was addressed by Bristow et al. (2010); B. Meteorology - The Harmattan winds form the Low Level Jet (Washington and Todd, 2005) and, C. Topography - the persistent surface winds blowing southwestward are focused toward the Bodélé depression by the structure of the valley between the Tibesti $(\sim 2600 \mathrm{~m})$ and Ennedi $(\sim 1000 \mathrm{~m})$ massifs (Koren et al., 2006).

During the winter months, dust emitted from the Bodélé depression is transported by the Harmattan winds southwestward over the Sahel toward the Gulf of Guinea into the Atlantic Ocean heading to the coast of South America (Kaufman et al., 2005a).

The extensive emitted dust mass, the tropical Atlantic northwesterly winds regime, and the observed crustal elements found in dust in the Amazon Basin suggest that North African dust reaches the Amazon forest. The exact North African dust sources that actually the dust is originating 
from, however, remains challenging. In contrast to previous studies who suggested the arrival of North African dust to the Amazon forest but showed no clear evidence for the exact source of the dust, the objective of this study is to use ground based measurements and remote sensing observations in order to show clear connection between dust source in North Africa and the Amazon basin. Herein, we present a detailed case study that integrates the data analysis approach to track Bodélé's dust to the Amazon region.

\section{Methods}

The objectives of AMAZE- 08 were to understand the sources and processes that regulate emissions, transformation and deposition of biogenic aerosol particles in the forest. Extensive ground based measurements were conducted between 7 February and 14 March 2008 during the wet season. The AMAZE-08 site was $60 \mathrm{~km}$ NNW of Manaus and located within a mostly pristine rainforest (Chen et al., 2009; Martin et al., 2010).

We analyzed North African dust emissions and transport along the dust route during this period, using surface and remote sensing measurements. The surface wind speed and azimuth were estimated by probing the propagation of a dust front between the morning overpass of the MODerate resolution Imaging Spectroradiometer (MODIS) instrument on board Terra and the afternoon MODIS-Aqua satellites measurements, using the $1 \mathrm{~km}$ resolution blue band $(440 \mathrm{~nm})$ data (Koren and Kaufman, 2004). Time of emission in Africa was estimated by back propagating the dust front to the source, using the derived wind speed. Dust passage was monitored at the Ilorin AErosol RObotic NETwork (AERONET, Holben et al., 1998) station located in Nigeria $\left(8^{\circ} 19^{\prime} 12 \mathrm{~N}, 4^{\circ} 20^{\prime} 24 \mathrm{E}\right)$, along the dust pathway.

Dust mass was estimated at two locations, close to the source and over the ocean:

A. Near dust sources, which are far from any others aerosol sources, the observed Aerosol Optical Depth (AOD) was attributed solely to dust. The dust AOD was transformed to dust mass, $M_{\mathrm{du}}$, using the following relation:

$M_{\mathrm{du}}=2.7 A \tau_{\mathrm{du}}(g)$

where $A$ is the plume area (in $1 \mathrm{~km}$ resolution) and $\tau_{\mathrm{du}}$ is the mean dust AOD at the $550 \mathrm{~nm}$ band (at $10 \mathrm{~km}$ resolution) of the MODIS instrument (based on the deep blue data (Hsu et al., 2004)) located on Aqua. The factor $2.7( \pm 0.4) \mathrm{g} \mathrm{m}^{-2}$ is a result of regression calculations between the AOD in the visible $(550 \mathrm{~nm})$ and aerosol column concentration, based on several in-situ measurements in the North Africa region. The uncertainty in the mass calculations is $\pm 30 \%$ (for total AOD between 0.2 and 0.4, see Kaufmann et al., 2005a and the related references listed therein; Yu et al., 2009). Note that in cases when total AOD $>0.4$, the error may be larger.
B. Over the Atlantic Ocean, it is likely that dust particles are mixed with marine aerosol (sea salt, organic matter and oxidation products of dimethyl sulfide (Yu et al., 2009)) and biomass-burning aerosols from the Sahel region (Andreae et al., 1994; Formenti et al., 2008; Ansmann et al., 2009). This mixing increases the fine fraction, $f$, defined as the aerosol fraction with diameter smaller than $1 \mu \mathrm{m}$ (Kaufmann et al., $2005 \mathrm{~b}$ ). Therefore, over the ocean, the daily dust mass, $M_{\mathrm{du}}$, was estimated from Eq. (1), where $A$ is the area over the ocean covered by dust (between $20^{\circ} \mathrm{N}-15^{\circ} \mathrm{S}$, and $50^{\circ} \mathrm{W}-$ $\left.15^{\circ} \mathrm{E}\right) \cdot \tau_{\mathrm{du}}$ was extracted from the total AOD, $\tau$, and from $f$, using Eq. (2) (Kaufmann et al., 2005a; Yu et al., 2009):

$\tau_{\mathrm{du}}=\frac{\tau\left(f_{\mathrm{a}}-f\right)-\tau_{\mathrm{m}}\left(f_{\mathrm{a}}-f_{\mathrm{m}}\right)}{f_{\mathrm{a}}-f_{\mathrm{d}}}$

$\tau$ and $f$ were products of the $550 \mathrm{~nm}$ band of the MODIS instrument (both in $1^{\circ}$ resolution) located on the Terra and Aqua satellites. The fine fraction, $f$, is assumed to be composed of 3 main types of aerosol, as described by Eq. (3) (Kaufman et al., 2005a)

$f=f_{\mathrm{a}}+f_{\mathrm{m}}+f_{\mathrm{d}}$

were $f_{\mathrm{a}}, f_{\mathrm{m}}, f_{\mathrm{d}}$ are the anthropogenic, maritime and dust fine fractions $(0.90,0.45$ and 0.37 , respectively, with estimated error of 20\%) as estimated over selected regions (Yu et al., 2009). The AOD attributed to maritime aerosol, $\tau_{\mathrm{ma}}$, was based on Eq. (4) (Smirnov et al., 2003; Kaufmann et al., 2005a):

$\tau_{\mathrm{ma}}=0.007 W \pm 0.02$

where $W$ is the magnitude of the wind speed at $1000 \mathrm{hPa}$, obtained from the National Center for Environmental Prediction reanalysis (Kalnay et al., 1996).

The propagation of the dust/biomass-burning plumes was further analyzed by studying the polarization signal of the plumes, using the Cloud-Aerosol LIdar with Orthogonal Polarization (CALIOP) instrument on board the CloudAerosol Lidar and Infrared Pathfinder Satellite Observation (CALIPSO) satellite (Thomason et al., 2007). In order to enhance the backscatter signal, the vertical (up to $8 \mathrm{~km}$ ) and the horizontal resolution of the profiles were reduced to $60 \mathrm{~m}$ ( 2 signal points) and $5 \mathrm{~km}$ (15 signal points), respectively. In contrast to other types of aerosols, dust particles are dominated by no spherical particles, and therefore their Volume Depolarization Ratio (VDR, i.e., the ratio of the perpendicular to parallel components of the attenuated backscatter at $532 \mathrm{~nm}$, including aerosol and molecular scattering) is expected to be relatively high, approximately between 0.1 to 0.4 (Murayama et al., 2001; Liu et al., 2008a, b, c).

The distinction between aerosols and clouds was based on (a) the VDR and (b) the different backscatter patterns (Ben Ami et al., 2009): we assumed that clouds have strong backscatter signal, and either sporadic and large vertical dimension (cumulus clouds) or continuous horizontal shape 
(stratiform clouds). Aerosol plumes, on the other hand, have a continuous horizontal and vertical structure with wide horizontal dimension and weaker backscatter signal.

The propagation of the dust over the Atlantic Ocean was also studied by analyzing the spatial distribution of the AOD from MODIS along the center of the dust/biomass-burning plumes (between $10^{\circ} \mathrm{N}-5^{\circ} \mathrm{S}$, and $50^{\circ} \mathrm{W}-10^{\circ} \mathrm{E}$ ).

At the AMAZE-08 field station $\left(2^{\circ} 35^{\prime} 22^{\prime \prime} \mathrm{S}\right.$, $60^{\circ} 06^{\prime} 55^{\prime \prime} \mathrm{W}$ ), aerosol particles having diameters smaller than $2.0 \mu \mathrm{m}$ as well as those in the size range from 2.0 to $10 \mu \mathrm{m}$ were collected from above the rain forest canopy, using Stacked Filter Units with Nuclepore filters. Elemental analysis of collected particles was carried out by Particle Induced X-ray Emission (PIXE) (Artaxo et al., 1987).

The transport of the dust, from the Bodélé depression towards the Amazon Basin, was estimated also by trajectories of the dust-containing air parcels via the HYbrid SingleParticle Lagrangian Integrated Trajectory (HYSPLIT) model (Draxler and Rolph, 2003).

\section{Results}

The results are presented in four stages, from source to sink, showing correlations that link each subsequent stage to the previous one:

1. Analysis of the Bodélé depression emission pattern.

2. Analysis of aerosol properties over the Ilorin AERONET station near the Gulf of Guinea.

3. Analysis of the transport of air masses over Africa and over the Atlantic Ocean.

4. Elemental analysis (by PIXE) of aerosols collected at the AMAZE-08 field site in Central Amazonia.

5. Forward trajectories of air parcels originated from the Bodélé depression.

\subsection{Analysis of the Bodélé depression emission pattern}

During the period of this study, between February 2008 and mid March, the Bodélé depression was the most active dust source in North Africa (Fig. 1). On February 2008, the activity in the Bodélé depression was characterized by two periods of dust emission between 6-8 and 11-16 February, followed by an extensive emission between 18-27 February. During early and mid-March, the Bodélé was significantly less active. Additional dust activity with much smaller magnitude was observed in other nearby sources. On a few occasions, the activity in the Bodélé was accompanied by significant emissions from other sources along the Moroccan coastline (not shown). These plumes, for the most part, propagated northwest, away from the South American coastline. Figure 1 illustrates the dominance of the Bodélé depression, in comparison to other dust sources.

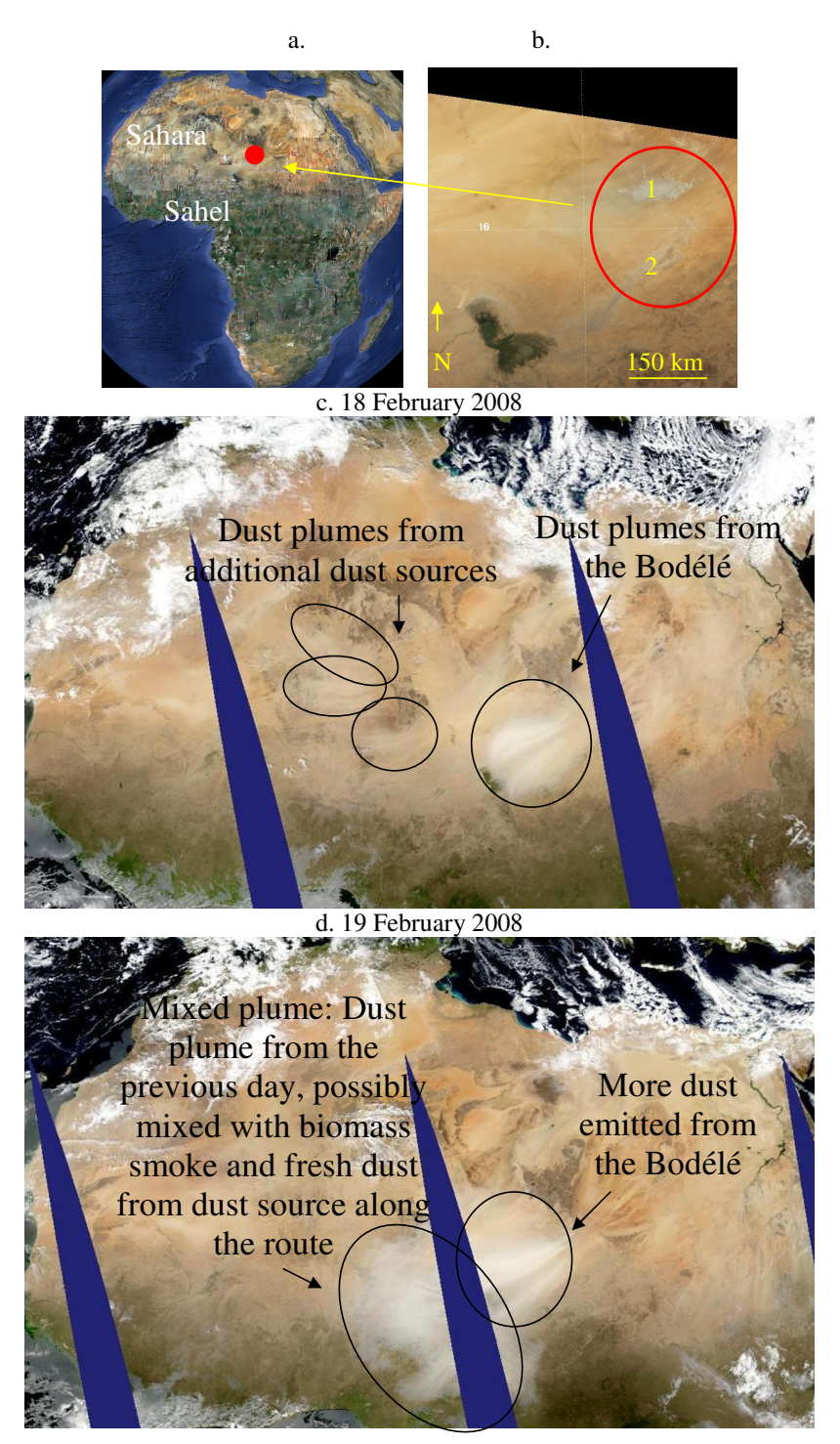

Fig. 1. (a) The location of the Bodélé depression (marked with red); (b) The Bodélé depression (composed of two main dust sources, marked in red) on a clear day (5 March 2008); (c-d) daily images of North Africa as seen by the MODIS instrument on board the Aqua satellite (collection 005) for 18 and 19 February, for the region between $37^{\circ} \mathrm{N}-5^{\circ} \mathrm{S}$ and $17^{\circ} \mathrm{W}-35^{\circ} \mathrm{E}$. Blue regions marked area with no satellite coverage. The gaps between two aerosol plumes are equivalent to emission less periods (usually nighttime). The images are taken from http://modis-250m.nascom.nasa.gov/.

Frequently, the dust originated from the Bodélé is emitted from two sources: the main source area, northeast and within the large ephemeral lake (point 1 in Fig. 1b) and a second smaller source area $\sim 150 \mathrm{~km}$ south of the lake which is not always active (point 2 in Fig. 1b).

The emission pattern analysis is based on five emission days (16, 20, 24, 25 February and 22 March) that were selected based on MODIS coverage during the study period. 


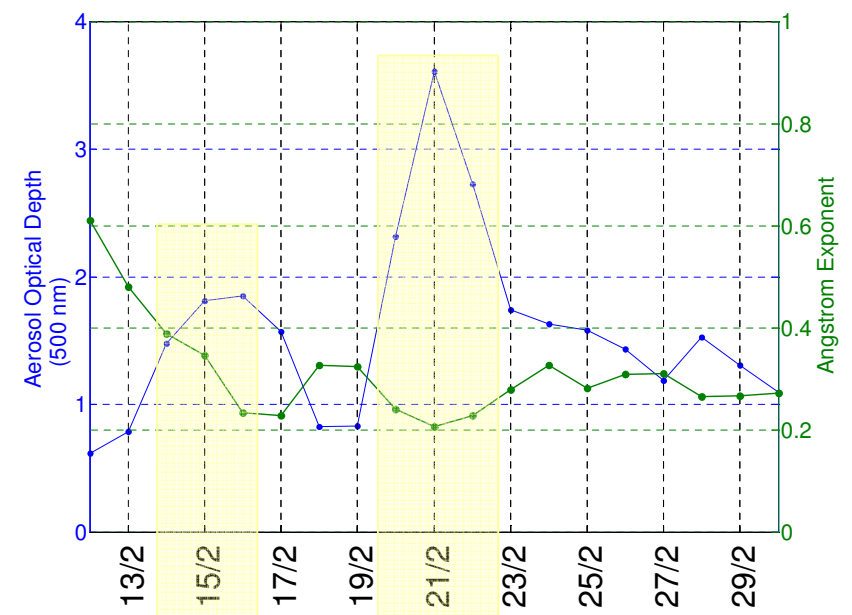

Fig. 2a. Level-2 AERONET AOD at $500 \mathrm{~nm}$ and Angstrom exponent for 440-870 nm during the period between 12 February and 1 March 2008. Periods of high AOD and low Angstrom exponent are marked with yellow rectangles.

The emission started during the early morning hours, approximately between 03:30 to 06:30 (local time), with surface wind speeds between 14.5 to $18 \mathrm{~m} \mathrm{~s}^{-1}$ and wind azimuth between $225^{\circ}$ and $250^{\circ}$. The emitted plumes, observed by the Aqua satellite, covered an area between $12 \times 10^{3}$ and $100 \times 10^{3} \mathrm{~km}^{2}$. The average AOD of the plumes varied between 2 and 3.9 (most likely underestimated), and the emitted mass per emission day (up to about 12:30) varied between $1 \times 10^{5}$ and $1 \times 10^{6}$ tonne. The emitted mass was equivalent to an emission flux between 2.7-40 t s $\mathrm{s}^{-1}$ (based on different durations of emission).

The estimated time of emission, surface wind azimuth and emission flux are in agreement with the analysis of Koren and Kaufman (2004) and Koren et al. (2006). The estimated surface wind speed is slightly higher than measurements done by Koren and Kaufman (2004) and Koren et al. (2006); however, it is in line with the suggested minimum threshold speed for dust emission of 10-11 m s${ }^{-1}$ (Koren and Kaufman 2004; Todd et al., 2007).

A special case is the dust emission during 18 February, which was characterized by early emission (starting approximately at 23:30) and a large emitted mass of $\sim 2 \times 10^{6}$ tonne (up to noon local time). The extensive dust emission continued on 19 February. The emission of the Bodélé then persisted for seven more days until 27 February.

\subsection{Analysis of aerosol properties over the Ilorin AERONET station.}

Focusing on two emission periods, 11-16 and 18-27 February, we followed the dust plumes along their routes westward toward the Gulf of Guinea. During 14-16 and 20-22 February, the Ilorin AERONET station (located at

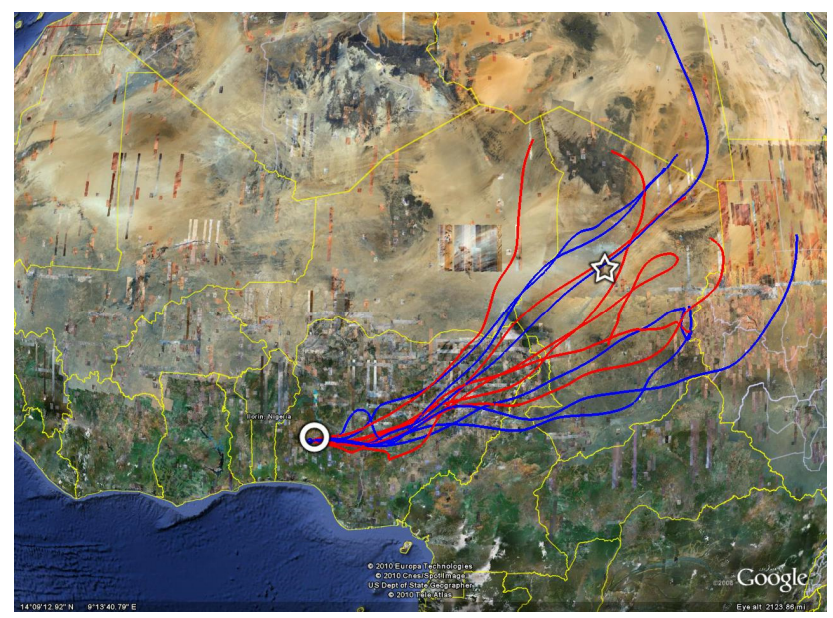

Fig. 2b. Back trajectories starting from the Ilorin AERONET station (white circle) during 14-16 and 20-22 February, starting at $1000 \mathrm{~m}$ (red) and $2000 \mathrm{~m}$ (blue) above ground level (starting at 12:00 UTC), calculated via HYSPLIT model. The location of the Bodélé depression is marked with white star.

$\left.8^{\circ} 19^{\prime} \mathrm{N}, 4^{\circ} 20^{\prime} \mathrm{E}\right)$ measured a significantly increased AOD (most likely underestimated), accompanied by a decrease of the Angstrom exponent ( $\AA$, Eck et al., 1999). Small Å values indicate the presence of large particles such as dust. Significant emissions, starting on 18 February, are reflected in the AOD values (Fig. 2a). Back trajectory calculations from Ilorin station, during 14-16 and 20-22 February, suggest that the air masses passed over the Bodélé region (Fig. 2b) and that the transport time was $\sim 2.5$ days.

\subsection{Analysis of the transport of air masses over Africa and over the Atlantic Ocean}

The propagation of the dust plumes over North Africa was analyzed using CALIOP vertical profiles. Over the Atlantic Ocean, we used CALIOP and MODIS measurements. Figures $3 \mathrm{a}$ and $\mathrm{b}$ show the propagation of the dust/biomassburning plumes during the study period, beginning near the source, continuing over the Atlantic and finally toward the Amazon Basin. It can be seen that the dust event is composed of two major plumes (as observed by MODIS, Fig. 1c and d) with top heights near 1.2 and $2 \mathrm{~km}$ (for 19 February), both emitted from the Bodélé. As the dust propagated southwest from the Bodélé, it mixed with biomass burning smoke. From the mixing region over Nigeria, the dust and the biomass smoke continued together, as shown in the VDR analysis. The comparison between Fig. 3a and b with observations from a day without a dense aerosol plume (Fig. 4) clearly emphasizes the presence of the dust and the biomassburning aerosols over the marine boundary layer during the period of the study. 


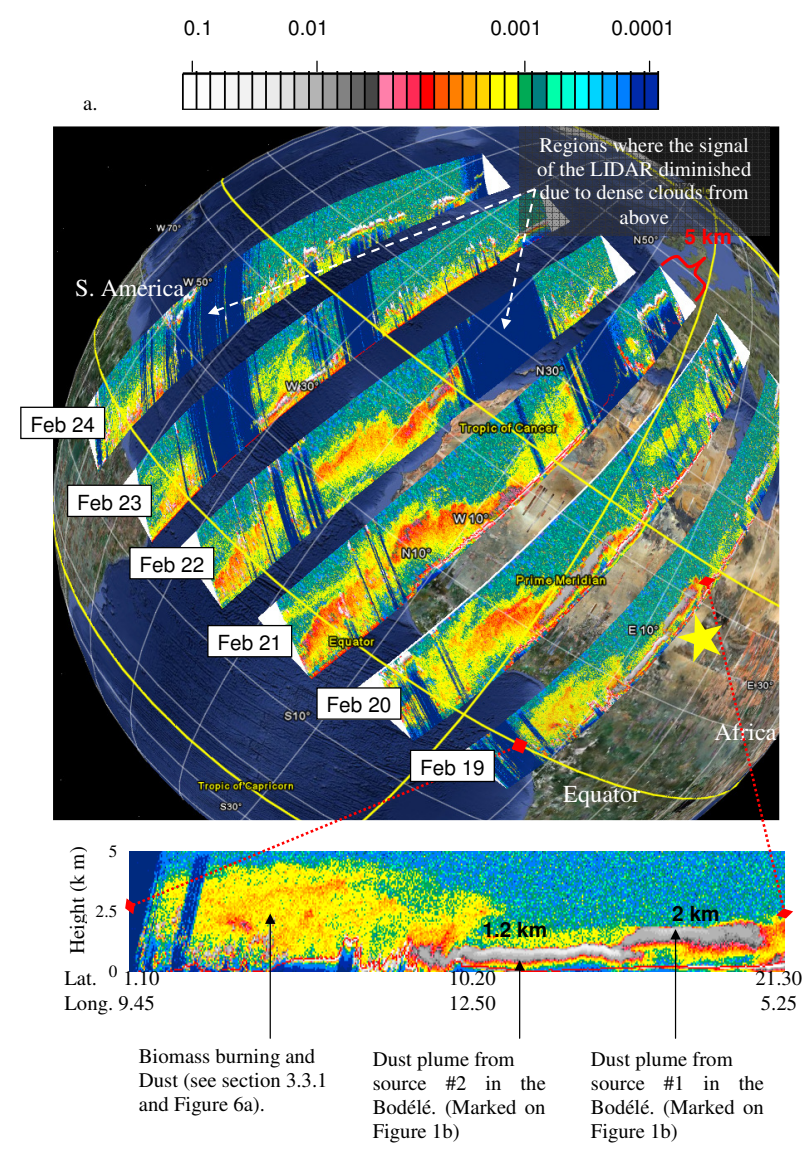

Fig. 3a. CALIOP nighttime vertical attenuated backscatter profiles $\left(\mathrm{km}^{-1} \mathrm{~s}^{-1}\right)$ in the $532 \mathrm{~nm}$ band, plotted over the study area. The vertical profiles are $5 \mathrm{~km}$ in height (February 2008). The location of the Bodélé is marked by a yellow star. The lower enlargement shows the interaction region between the biomass-burning smoke and the dust plumes. The dust is recognized by the strong backscattering signal relative to the biomass-burning plume (the data was verified with MODIS).

\subsubsection{Volume depolarization ratio analysis}

VDR, retrieved from the vertical profiles of CALIOP, is a function of CALIPSO wavelength and the size and shape of the targets particles and air molecules. Therefore, the acquired VDR is in fact a result of different types of interactions.

The histogram of the area covered by the aerosol plumes showed that most of the values fell between $\sim 0.1$ to $\sim 0.4$ (Fig. 5). These VDR values, which are typical for dust (Liu et al., 2008a, b, c; Tesche et al., 2009), indicate that the majority of the observed signal (during the period of the study) was obtained from dust particles. The obtained values are also in agreement with results of $0.31 \pm 0.03$ (Freudenthaler et al., 2009) attributed solely to dust particles. The relatively high values, namely more signal at the perpendicular band of CALIOP, derived from the irregular

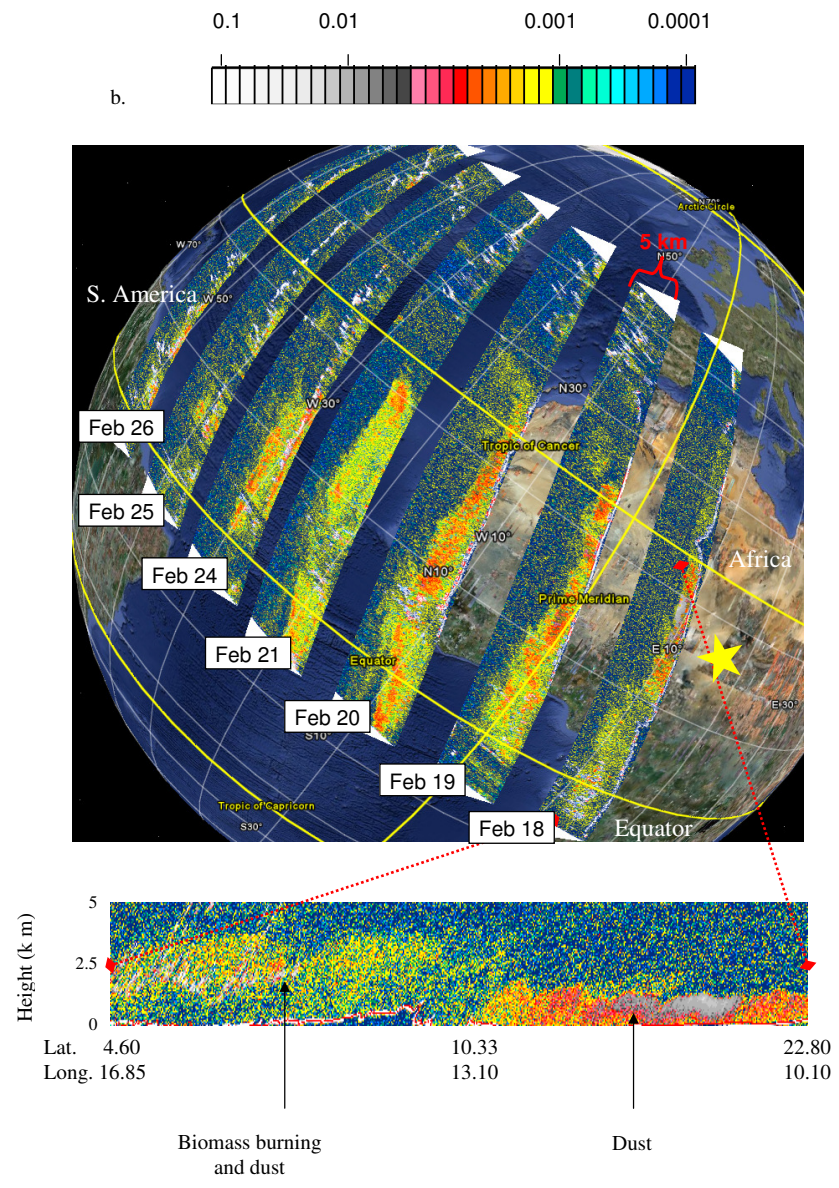

Fig. 3b. As Fig. 3a, but for daytime profiles and for $1064 \mathrm{~nm}$ wavelength.
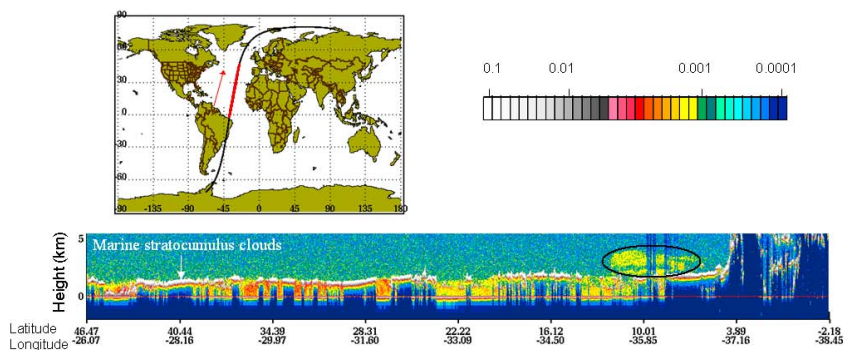

Fig. 4. A CALIOP nighttime vertical attenuated backscatter profile $\left(\mathrm{km}^{-1} \mathrm{sr}^{-1}\right)$ in the $532 \mathrm{~nm}$ band from 2 February 2008: An example of a CALIOP profile where one see the height of the marine boundary layer (marked by the height of the marine stratocumulus clouds) with almost no presence of dense aerosol above it. Aerosols above the marine boundary layer are marked by an ellipse. The CALIPSO track and the direction of the flight are shown on the upper part (red). 


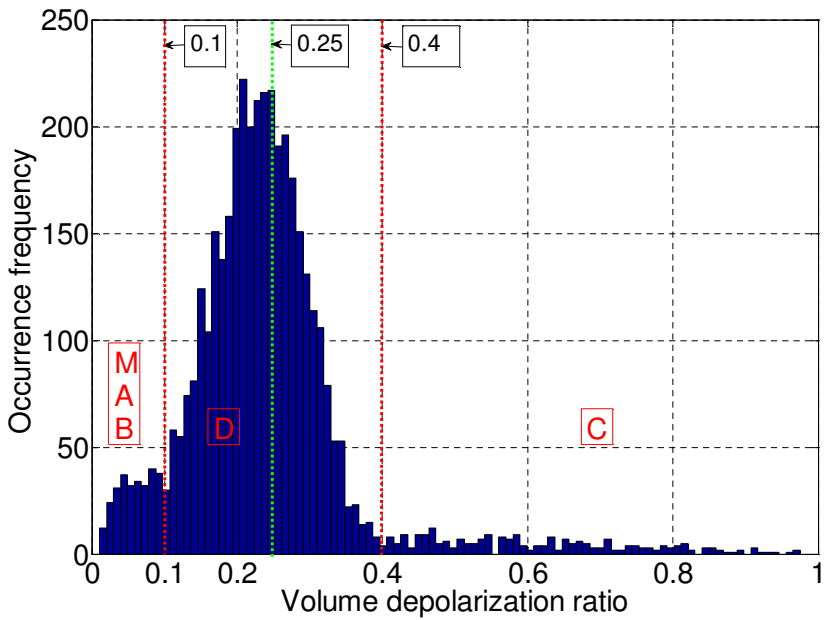

Fig. 5. Frequency of occurrence of VDR, obtained from the vertical area covered by the aerosol plumes for the area between $40^{\circ} \mathrm{N}$ and $5^{\circ} \mathrm{S}$ and between $17^{\circ} \mathrm{E}$ and $46^{\circ} \mathrm{W}$ as seen in Fig. 3a (based on CALIOP nighttime profiles between 19-24 February 2008). The edges of the plumes are defined based on the VDR and different backscatter patterns (see Sect. 2). Aerosols located in the marine boundary layer (for which the height of the marine boundary layer was defined based on the location of marine stratocumulus clouds, Ben-Ami et al., 2009) were excluded from the analysis, and therefore the VDR obtained from sea salt is expected to be minor. VDR regions dominated by air molecules (M), anthropogenic (A), biomass-burning (B), dust (D) aerosol and clouds (C) are marked in red. Note that the small peak of VDR $<0.1$ was mostly from data taken on 19 February (see Fig. 6b). The threshold for pure dust $(0.25)$ is marked by a green line.

shape of the dust and from multiple scattering. Note that in a case of high AOD the signal of CALIPSO, obtained from the lower part of the aerosol plume, may have a lower quality.

Water clouds located near or within the aerosol plume, have higher VDR values (between 0.4 to 1 ) due to multiple scattering and were a minor contribution to the overall sampled signal. Anthropogenic aerosols, such as biomass smoke and molecules, which are much smaller compared to the CALIOP wavelength, have low VDR values, between 0 to 0.1 (Liu et al., $2008 \mathrm{a}, \mathrm{b}, \mathrm{c}$ ).

Most of the signal is attributed to dust since most of the VDR data is within 0.1-0.4. To emphasize the location of cleaner dust within the transported aerosol plume, we showed regions where the VDR is larger than 0.25 (the threshold is marked on Fig. 5) and smaller than 0.4. This relatively high value indicates that the selected regions are dominated by dust. Based on this assumption, several regions of relatively pure dust, as well as regions characterized by biomass burning mixed with dust (with lower VDR values) are marked in Fig. 6a. Close to the source (19 February), the aerosol plume is composed of (a) biomass burning mixed with dust in the southern parts of the aerosol plume (VDR of 0.19), (b) relatively pure dust in the central part of the plume (VDR of 0.31) and apparently (c) anthropogenic aerosol (VDR between 0 to $\sim 0.13$ ), most likely transported from North Libya and/or Europe over the Mediterranean (Duncan et al., 2008), in the northern part (Fig. 6a). This assumption was supported by back trajectories from HYSPLIT model, showing that the air parcel from the northern part of Fig. 6a (for 19 February, between latitudes $\sim 22 \mathrm{~N}^{\circ}$ and $\sim 30 \mathrm{~N}^{\circ}$ ) passed over Europe and the Mediterranean, heading central North Africa (not shown).

The tri-modal distribution of these aerosols is also evident in Fig. 6b. The VDR values of $\sim 0.3$ are in line with previous studies, and the VDR value of $\sim 0.19$ is significantly larger than that of $<0.1$ expected for pure biomass smoke (Liu et al., 2008a, b, c), indicating that the biomass smoke is mixed with dust particles.

The mixing of both types of aerosol over the Atlantic Ocean, as well as sedimentation of large dust particles along the transport route, is also evident from the shift of the center of the VDR distribution (Fig. 6b) from 0.32 over Africa to 0.15 over the western Atlantic.

Detailed analysis of the regions that are dominated by dust (marked with red in Fig. 6a) shows that the VDR decreases over time during transport, possibly due to extensive sedimentation of large dust particles. An opposite trend of increasing VDR (from 0.19 to 0.22 ) characterized the regions that are dominated by biomass burning mixed with dust (marked with green on Fig. 6a), indicating that more dust is dissipating toward the air mass containing the biomass burning. Further west (22-24 February), the VDR decreases again, most likely due to aerosol wet removal and sedimentation.

\subsubsection{Analysis with MODIS AOD}

As the dust plume continued to move away from its source, the spectral signal of the dust weakened, and it was more difficult to observe the dust via MODIS's spectral bands. However, the spatial and temporal distribution of MODIS AOD, calculated as latitudinal daily averages along the center of the plume, clearly shows a significant increase of AOD, approximately from 17 February to 1 March (Fig. 7a). The spatial and temporal distribution of the fine fraction, $f$, also calculated as latitudinal daily averages along the center of the plume, is in good agreement with the spatial and temporal pattern of the AOD (not shown). The suggestion is that periods of high AOD were characterized by the presence of a significant coarse fraction, presumably dust. The longitudinal distribution of the AOD, which extended from the African coast to the South American coast $\left(50^{\circ} \mathrm{W}\right)$, suggests the arrival of North African dust as far as the edge of the Amazon region. Estimation of dust loading (Fig. 7b), which is contributed to all north African dust sources, proposed that the extensive dust emission increased the dust loading over the ocean (between $20^{\circ} \mathrm{N}-15^{\circ} \mathrm{S}$, and $50^{\circ} \mathrm{W}-15^{\circ} \mathrm{E}$ ) by more than $100 \%$. The spatial distribution of the AOD from 


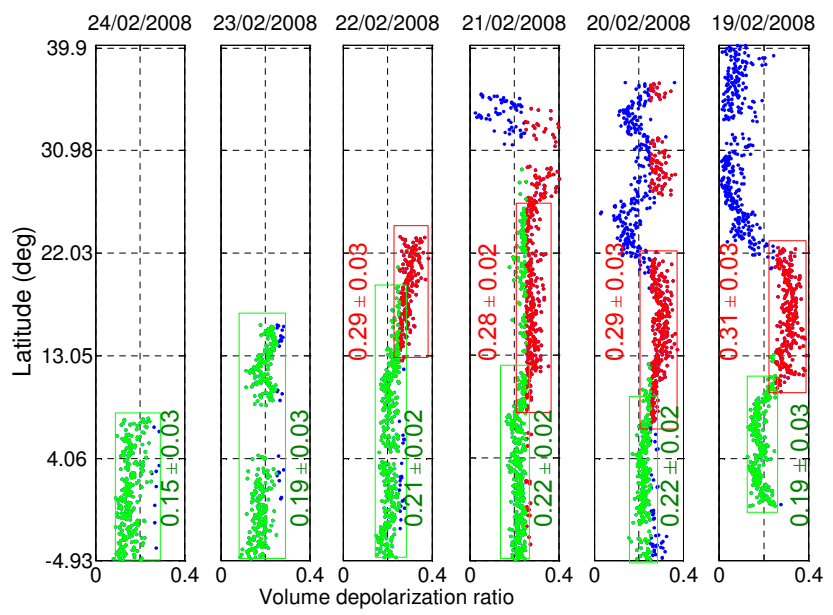

Fig. 6a. Vertical averaged VDR profiles of the aerosol plumes. The edges of the plumes are defined based on different backscatter patterns (see Sect. 2). Clouds were removed based on their relatively high VDR and on their spatial distribution. Aerosols located in the marine boundary layer (the height of the marine boundary layer was defined based on the location of marine stratocumulus clouds, BenAmi et al., 2009) were excluded from the analysis. Average VDR ( \pm one standard deviation) for selected regions of pure dust with VDR between 0.25 and 0.4 are marked in red, and regions of mixed biomass aerosol with dust $(0<\mathrm{VDR}<0.25)$ are marked in green. The blue-marked VDR along the aerosol plumes are those that are not classified by red or green.

17 February to 1 March is composed of minor and major peaks (marked in Fig. 7a) that are simultaneous with the two events of dust emissions that occurred during 11-16 and 1827 February, including the signature of these emissions in the Ilorin AERONET measurements (14-16 and 20-22 February). The upper part of Fig. 7a-b ( 5-9 February) show evidence for other period of emission.

\subsection{Elemental analysis (by PIXE) of aerosols collected at the AMAZE-08 field site in Central Amazonia}

The arrival of the dust in the Amazon region was observed at the AMAZE-08 field site between 22 and 26 February. Elemental analysis by PIXE of the aerosol showed an increase in the elements $\mathrm{Si}, \mathrm{Al}, \mathrm{Fe}, \mathrm{Mn}$ and $\mathrm{Ti}$ in the coarse and the fine fraction, all attributed to mineral dust emitted during 18 19 February (and possibly even earlier, during 11-16 February) from the Bodélé depression (Fig. 8). The significant increase in the observed crustal elements continued until about 4 March. During this period, the daily averaged concentration of the previously mentioned crustal elements increased by approximately one order of magnitude (i.e., from 0.076 to $0.79 \mu \mathrm{g} \mathrm{m}^{-3}$ and from 0.062 to $0.82 \mu \mathrm{g} \mathrm{m}^{-3}$ in the fine and coarse modes, respectively). The total mass of the above crustal elements during this period (between 22 February and 4 March) was $4.83 \mu \mathrm{g} \mathrm{m}^{-3}$. Increases in other elements

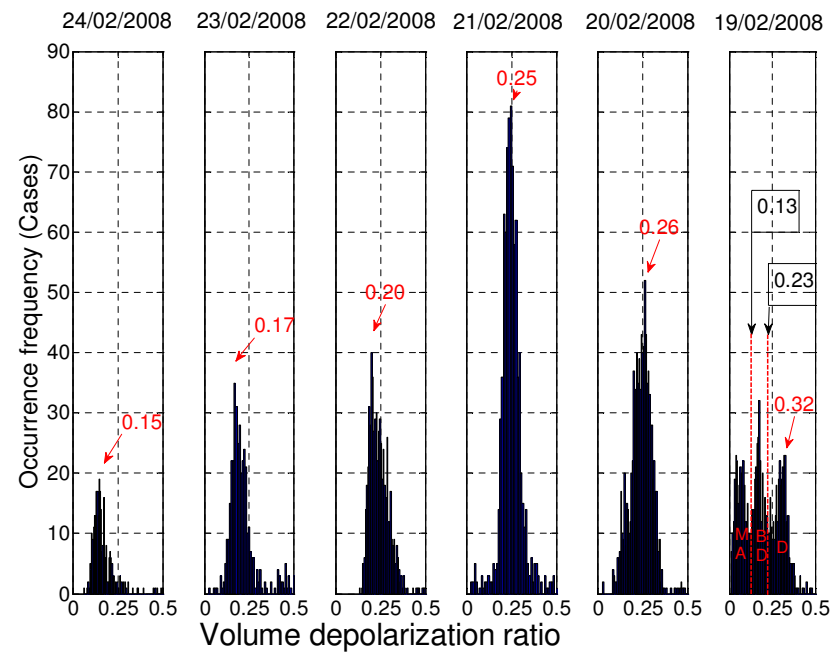

Fig. 6b. Frequency of occurrence of VDR (as in Fig. 5, but for all days) obtained from CALIOP nighttime profiles. Rare incidences of VDR $>0.5$ are not shown. VDR regions dominated by air molecules (M), anthropogenic (A), biomass-burning (B) and dust (D) aerosol are marked in red. a. AOD

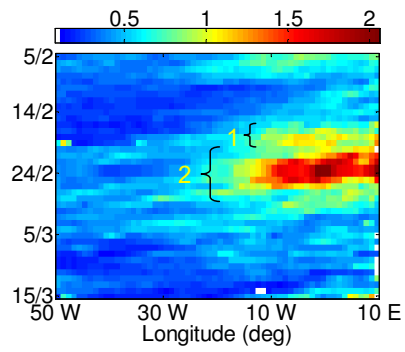

b. Dust mass

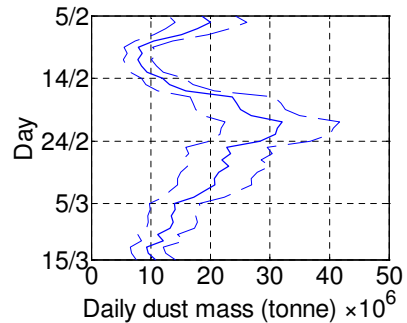

Fig. 7. Daily distribution of AOD and estimation of dust mass. Note that the area cover by (a) and (b) is not similar: (a) daily AOD distribution over the oceanic region. Each line of the figure is a daily latitudinal average for the rectangle region between $10^{\circ} \mathrm{N}-5^{\circ} \mathrm{S}$ and $50^{\circ} \mathrm{W}-10^{\circ} \mathrm{E}$. The data is based on MODIS AOD maps, in spatial resolution of one degree, as obtained from the Aqua and Terra satellites. The signature of dust emitted during (1) 11-16 February and (2) 18-27 February is indicated; (b) daily estimated dust mass (tonne) over the Atlantic Ocean between $20^{\circ} \mathrm{N}-15^{\circ} \mathrm{S}$ and $50^{\circ} \mathrm{W}-$ $15^{\circ} \mathrm{E}$ using Eq. (1-4). Uncertainty in the mass estimate is calculated based on $\pm 30 \%$ (dashed lines). Note that in cases when total $\mathrm{AOD}>0.4$, the error may be larger.

(not shown), such as S (in the coarse fraction), also occurred, most likely contributed by marine sources, possibly originating from dimethyl sulfide (DMS) oxidation. Chlorine also in the coarse fraction indicated that the dusty air plumes passed over the ocean and mixed with sea salt, as expected. Potassium, in the fine and coarse fraction, may be attributed either to arrival of dust or to a contribution of biomass burning aerosol, possibly originating from the Southern Sahel region. 


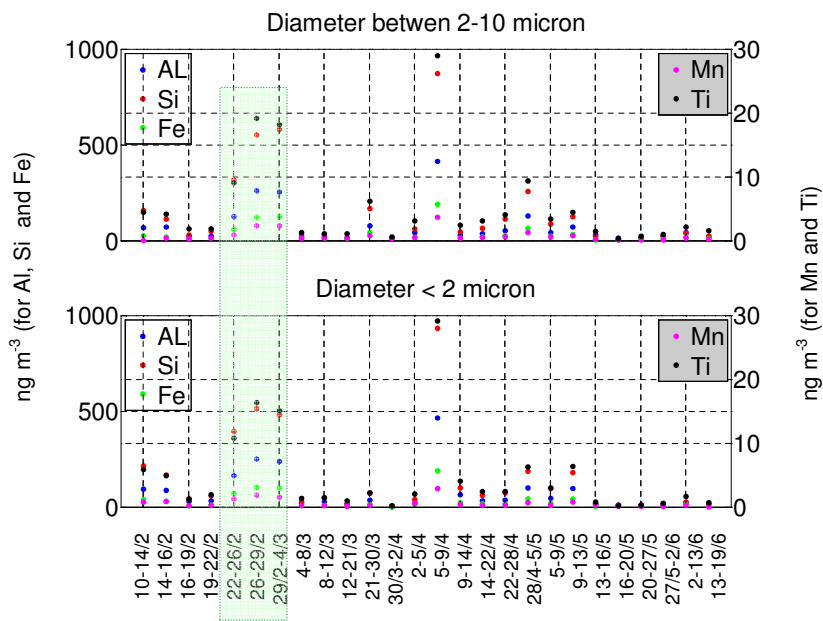

Fig. 8. Elemental composition of aerosol collected at the AMAZE08 field site in Central Amazonia during February and June 2008, (a) fine (diameter $<2.0 \mu \mathrm{m}$ ) and (b) coarse fraction $(2.0$ to $10 \mu \mathrm{m}$ ). The area in the green rectangle marks the dates for which crustal elements were enhanced. The left Y-axis refers to the concentrations of $\mathrm{Al}, \mathrm{Si}$, and $\mathrm{Fe}$. The right $\mathrm{Y}$-axis refers to the concentrations of $\mathrm{Mn}$ and $\mathrm{Ti}$.

The increase in crustal elements during additional periods, as seen in Fig. 8 (e.g.: during 5-9 April), suggests that this is not a singular event and that there are additional cases of North African dust transport to the Amazon Basin. Analysis of CALIOP profiles along the Brazilian coastline (for 24 February, Fig. 3a) showed that the aerosol plume attained a maximum height near $3.3 \mathrm{~km}$, while its base merged with the underlying boundary layer, in agreement with Ansmann et al. (2009).

\subsection{Forward trajectories of air parcels originated from the Bodélé depression.}

Forward trajectories, calculated using the HYSPLIT transport model, starting over the Bodélé depression at the levels of 0,500 , and $1000 \mathrm{~m}$ above ground level, propose that the increase of crustal elements between 22 and 26 February was contributed to dust emitted from the Bodélé (and the nearby sources) between $\sim 14$ and $\sim 15$ February (Fig. 9a). Similarly, the increase of crustal elements between 26 February and 4 March can be attributes to emission of dust from $\sim 18$ February and the following days (and partly to emission from previous days, Fig. 9b). The results of the model proposed that the dust arrived to the heart of the Amazon Basin (near $60^{\circ} \mathrm{W}$ ) in height between 1700 and $5000 \mathrm{~m}$ above ground level, and the transport time from the Bodélé to the Amazon Basin is between $\sim 10$ and $\sim 17$ days. a.
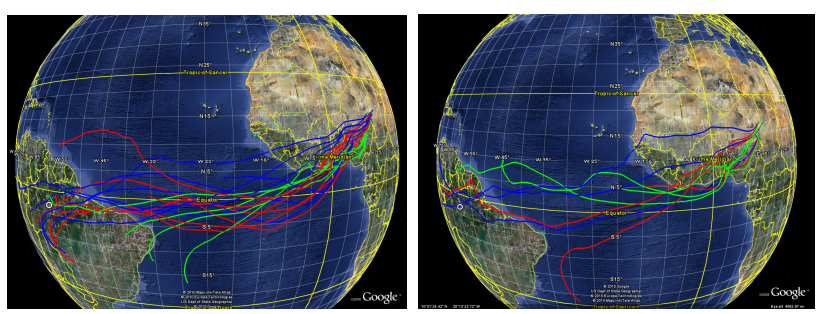

Fig. 9. Forward trajectories calculated using the HYSPLIT model, starting from several locations over the region of the Bodélé depression from the period between (a) 14 and 15 and (b) for 18 February 2008. The green, red and blue lines mark the height of the starting point at 0,500 and $1000 \mathrm{~m}$ above ground level. The region near Manaus is marked by a white circle.

\section{Conclusions}

Koren et al. (2006) suggested the Bodélé as source of nutrients for the Amazon Basin based on inductive reasoning without showing evidence for dust deposition. Here we present a detailed case study that closely follows dust emitted mainly from the Bodélé depression in Chad and deposited in the Amazon Basin. The AMAZE-08 measurements in the central Amazon show episodes of dust, biomass burning and marine aerosol elements, in agreement with the expected arrival time of the dust-laden air from the Bodélé, as retrieved by remote sensing measurements. The arrival of dust in the Amazon Basin is also in line with simultaneous in-situ measurements from AMAZE-08, showing enhancement in ice nuclei due to the presence of the dust particles (Prenni et al., 2009).

Nonetheless, despite the dominance of the Bodélé dust emissions, it is fair to assume contributions from additional dust sources along the transport path. We also assume that not all dust episodes (during winter in the Northern Hemisphere) reach the Amazon forest. For example, Lidar observations from one month before our case study (15 January to 14 February 2008), showed that dust/biomassburning plumes that originated from North Africa and were transported westward, were almost depleted of dust particles when they reached the Amazon region (Ansmann et al., 2009).

The Bodélé emission rates might be underestimated due to saturation of the AOD inversion algorithm $($ at $\sim \mathrm{AOD}=4)$ and the use of an AOD-to-mass conversion constant that is based on a compilation of many in-situ dust measurements and therefore should reflect average dust events and underestimate strong dust events. Moreover, our data is limited to the last daily satellite snapshots taken around 13:30 local time and therefore do not include dust that was emitted during the local afternoon (after the pass of the Aqua satellite over the region). Based on the spatial and temporal distribution of the VDR and the estimation of dust loading, we show 
that the Bodélé's activity is clearly reflected by changes in aerosol size distribution and dust loading over the tropical Atlantic.

Following the two emission periods (between 1116 February and between 18-27 February) and based on the relatively week emission between 11-13 February, the travel time from the source region to the heart of the Amazon Basin would be approximately between 8 and 12 days. The HYSPLIT results partly agree with the above suggestion.

Although further studies are needed, our study suggests that in addition, events with early emission starting time (around midnight) are likely to be strong dust events and are more likely to be transported and to reach the Amazon forest (during the winter season).

Acknowledgements. This research was partly funded by the Minerva foundation, with funding from the Federal German Ministry for Education and Research, and the German Israeli Science Foundation (GIF) Contract no. I-899-228.10/2005. Y. R. acknowledges support by the Helen and Martin Kimmel Award for Innovative Investigation. B. A. Y. acknowledges Jeremy Seltzer for proofreading.

Edited by: J. Schneider

\section{References}

Albrecht, B. A.: Aerosols, cloud microphysics, and fractional cloudiness, Science, 245, 1227-1230, 1989.

Andreae, M. O., Anderson, B. E., Blake, D. R., Bradshaw, J. D., Collins, J. E., Gregory, G. L., Sachse, G. W., and Shipham, M. C.: Influence of plumes from biomass burning on atmospheric chemistry over the equatorial Atlantic during CITE-3, J. Geophys. Res., 99, 12793-12808, 1994.

Ansmann, A., Baars, H., Tesche, M., Muller, D., Althausen, D., Engelmann, R., Pauliquevis, T., and Artaxo, P.: Dust and smoke transport from Africa to South America: lidar profiling over Cape Verde and the Amazon rainforest, Geophys. Res. Lett., 36, L11802, doi:10.1029/2009GL037923, 2009.

Artaxo, P. and Orsini, C.: PIXE and receptor models applied to remote aerosol source apportionment in Brazil, Nuclear Instruments \& Methods in Physics Research, B22, 259-263, 1987.

Artaxo, P., Maenhaut, W., Storms, H., and Grieken, R. V.: Aerosol characteristics and sources for the Amazon Basin during the wet season, J. Geophys. Res., 95, 16971-16986, 1990.

Artaxo, P. and Hansson, H.C.: Size distribution of biogenic aerosol particles from the Amazon Basin, Atmos. Environ., 29, 393-402, 1994.

Ben-Ami, Y., Koren, I., and Altaratz, O.: Patterns of North African dust transport over the Atlantic: winter vs. summer, based on CALIPSO first year data, Atmos. Chem. Phys., 9, 7867-7875, doi:10.5194/acp-9-7867-2009, 2009.

Bristow, C., Drake, N., and Armitage, S.: Deflation in the dustiest place on Earth: the Bodélé depression, Chad, Geomorphology, 105, 50-58, 2009.

Bristow, C. S., Hudson-Edwards, K. A., and Chappell, A.: Fertilizing the Amazon and Equatorial Atlantic with West African dust,
Geophys. Res. Lett., 37, L14807, doi:10.1029/2010GL043486, 2010.

Carlson, T. N. and Prospero, J. M.: The large-scale movement of Saharan Air outbreaks over the Northern Equatorial Atlantic, J. Appl. Meteor., 11, 283-297, 1972.

Chappell, A., Warren, A., O'Donoghue, A., Robinson, A., Thomas, A., and Bristow, C.: The implications for dust emission modeling of spatial and vertical variations in horizontal dust flux and particle size in the Bode'le Depression, Northern Chad, J. Geophys. Res., 113, D04214, doi:10.1029/2007JD009032, 2008.

Chen, Q., Farmer, D. K., Schneider, J., Zorn, S. R., Heald, C. L., Karl, T. G., Guenther, A., Allan, J. D., Robinson, N., Coe, H., Kimmel, J. R., Pauliquevis, T., Borrmann, S., Pöschl, U., Andreae, M. O., Artaxo, P., Jimenez, J. L., and Martin, S. T.: Mass spectral characterization of submicron biogenic organic particles in the Amazon Basin, Geophys. Res. Lett., 36, L20806, doi:10.1029/2009GL039880, 2009.

Davidson, E. A. and Artaxo, P.: Globally significant changes in biological processes of the Amazon Basin: results of the Large-scale Biosphere-Atmosphere Experiment, Glob. Change Biol., 10, 111, 2004.

Draxler, R. R. and Rolph, G. D.: HYSPLIT (HYbrid Single-Particle Lagrangian Integrated Trajectory) Model access via NOAA ARL READY Website. http://www.arl.noaa.gov/ready/hysplit4.html, NOAA Air Resources Laboratory, Silver Spring, MD, 2003.

Duncan, B. N., West, J. J., Yoshida, Y., Fiore, A. M., and Ziemke, J. R.: The influence of European pollution on ozone in the Near East and northern Africa, Atmos. Chem. Phys., 8, 2267-2283, doi:10.5194/acp-8-2267-2008, 2008.

Eck, T. F., Holben, B. N., Reid, J. S., Dubovik, O., Smirnov, A., O'Neill, N. T., Slutsker, I., and Kinne, S.: Wavelength dependence of the optical depth of biomass burning, urban, and desert dust aerosols, J. Geophys. Res., 104, 31333-31349, 1999.

Engelstaedter, S., Washington, R., and Mahowald, N.: Impact of changes in atmospheric conditions in modulating summer dust concentration at Barbados: A back-trajectory analysis, J. Geophys. Res., 114, D17111, doi:10.1029/2008JD011180, 2009.

Falkowski, P. G., Barber, R. T., and Smetacek, V.: Biogeochemical Controls and Feedbacks on Ocean Primary Production, Science, 281, 200-206, 1998.

Formenti, P., Andreae, M. O., Lange, L., Roberts, G., Cafmeyer, J., Rajta, I., Maenhaut, W., Holben, B. N., Artaxo, P., and Lelieveld, J.: Saharan dust in Brazil and Suriname during the Large-Scale Biosphere-Atmosphere Experiment in Amazonia (LBA) - Cooperative LBA Regional Experiment (CLAIRE) in March 1998, J. Geophys. Res., 106, 14919-14934, 2001.

Formenti, P., Rajot, J. L., Desboeufs, K., Caquineau, S., Chevaillier, S., Nava, S., Gaudichet, A., Journet, E., Triqute, S., Alfaro, S., Chiari, M., Haywood, J., Coe, H., and Highwood, E.: Regional variability of the composition of mineral dust from western Africa: Results from the AMMA SOP0/DABEX and DODO field campaigns, J. Geophys. Res., 113, D00C13, doi:10.1029/2008JD009903, 2008.

Freudenthaler, V., Esselborn, M., Wiegner, M., Heese, B., Tesche, M., Ansmann, A., Mueller, D., Althausen, D., Wirth, M., Fix, A., Ehret, G., Knippertz, P., Toledano, C., Gasteiger, J., Garhammer, M., and Seefeldner, M.: Depolarization-ratio profiling at several wavelengths in pure Saharan dust during SAMUM 2006, Tellus B, 61, 165-179, 2009. 
Garrison, V. H., Shinn, E. A., Foreman, W. T., Griffin, D. W., Holmes, C. M., Kellogg, C. A., Majewski, M. S., Richardson, L. L., Ritchie, K. B., and Smith, G. W.: African and Asian dust: from desert soils to coral reefs, Bioscience, 53, 469-480, 2003.

Generoso, S., Bey, I., Labonne, M., and Br'eon, F. M.: Aerosol vertical distribution in dust outflow over the Atlantic: Comparisons between GEOS-Chem and Cloud-Aerosol Lidar and Infrared Pathfinder Satellite Observation (CALIPSO), J. Geophys. Res., 113, D24209, doi:10.1029/2008JD010154, 2008.

Ginoux, P., Prospero, J. M., Torres, O., and Chin, M.: Long-term simulation of global dust distribution with the GOCART model: correlation with North Atlantic Oscillation, Environ, Modell Softw, 19(2), 113-128, 2004.

Ginoux, P., Garbuzov, D., and Hsu, N. C.: The identification of anthropogenic and natural dust sources using MODIS Deep Blue Level 2 data, J. Geophys. Res., 115, D05204, doi:10.1029/2009JD012398, 2010.

Griffin, D. W. and Kellogg, C. A.: Dust storms and their impact on ocean and human health: dust in earth's atmosphere, Ecohealth, 1, 248-295, 2004.

Holben, B. N., Eck, T. F., Slutsker, I., Tanre, D., Buis, J. P., Setzer, A., Vermote, E., Reagan, J. A., Kaufman, Y. J., Nakajima, T., Lavenu, F., Jankowiak, I., and Smirnov, A.: AERONET-A federated instrument network and data archive for aerosol characterization, Remote Sens. Environ., 66(1), 1-16, 1998.

Hsu, N. C., Tsay, S. C., King, M. D., and Herman, J. R.: Aerosol properties over bright-reflecting source regions, IEEE Trans. Geosci. Remote Sens., 42, 557-569, 2004.

Huang, J., Zhang, C., and Prospero, J. M.: African dust outbreaks: a satellite perspective of temporal and spatial variability over the tropical Atlantic Ocean, J. Geophys. Res., 115, D05202, doi:10.1029/2009JD012516, 2010.

Jiang, H, Xue, H., Teller, A., Feingold, G., and Levin, Z.: Aerosol effects on the lifetime of shallow cumulus, Geophys. Res. Lett., 33, L14806, doi:10.1029/2006GL026024, 2006.

Jickells, T. D., An, Z. S., Andersen, K. K., Baker, A. R., Bergametti, G., Brooks, N., Cao, J.J., Boyd, P. W., Duce, R. A.,. Hunter, K. A, Kawahata, H., Kubilay, N., laRoche, J., Liss, P. S., Mahowald, N., Prospero, J. M., Ridgwell, A. J., Tegen, I., and Torres, R.: Global Iron Connections Between Desert Dust, Ocean Biogeochemistry and Climate, Science, 308, p. 67-71, 2005.

Kalnay, E., Kanamitsu, M., Kistler, R., Collins, W., Deaven, D., Gandin, L., Iredell, M., Saha, S., White, G., Woollen, J., Zhu, Y., Leetmaa, A., Reynolds, R., Chelliah, M., Ebisuzaki, W., Higgins, W., Janowiak, J., Mo, K. C., Ropelewski, C., Wang, J., Jenne, R., and Joseph, D.: The NCEP/NCAR 40-Year Reanalysis Project, Bull. Amer. Met. Soc., 3, 43-471, 1996.

Karyampudi, V. M., Palm, S. P., Reagan, J. A., Fang, H., Grant, W. B., Hoff, R. M., Moulin, C., Pierce, H. F., Torres, O., Browell, E. V., and Melfi, S. H.: Validation of the Saharan dust plume conceptual model using lidar, Meteosat, and ECMWF data, B. Am. Meteorol. Soc., 80, 1045-1075, 1999.

Kaufman, Y. J., Koren, I., Remer, L. A., Tanre, D., Ginoux, P., and Fan, S.: Dust transport and deposition observed from the Terra-Moderate Resolution Imaging Spectroradiometer (MODIS) spacecraft over the Atlantic Ocean, J. Geophys. Res., 110, D10S12, doi:10.1029/2003JD004436, 2005a.

Kaufman, Y. J., Boucher, O., Tanre, D., Chin, M., Remer, L, and Takemura, T.: Aerosol anthropogenic component esti- mated from satellite data, Geophys. Res. Lett., 32, L17804, doi:10.1029/2005GL023125, 2005b.

Kaufman, Y. J, Koren, I., Remer, L. A., Rosenfeld, D., and Rudich, Y.: The Effect of Smoke, Dust and Pollution Aerosol on Shallow Cloud Development Over the Atlantic Ocean, P. Natl. Acad. Sci., 102(32), 11207-11212, 2005c.

Koren, I. and Kaufman, Y. J.: Direct wind measurements of Saharan dust events from Terra and Aqua satellites, Geophys. Res. Lett., 31, L06122, doi:10.1029/2006GL026024, 2004.

Koren, I., Kaufman, Y. J., Rosenfeld, D., Remer, L. A., and Rudich, Y.: Aerosol invigoration and restructuring of Atlantic convective clouds, Geophys. Res. Lett., 32, LI4828, doi:10.1029/2005GL023187, 2005.

Koren, I., Kaufman, Y. J., Washington, R., Todd, C. C., Rudich, Y., Martins, J. V., and Rosenfeld, D.: The Bod'el'e depression: a single spot in the Sahara that provides most of the mineral dust to the Amazon forest, Environ. Res. Lett., 1, 1-5, 2006.

Levin, Z., Ganor, E., and Gladstein, V.: The effects of desert particles coated with sulfate on rain formation in the eastern Mediterranean, J. Appl. Meteor., 35, 1511-1523, 1996.

Liu, D., Wang, Z., Liu, Z., Winker, D., and Trepte, C. A.: height resolved global view of dust aerosols from the first year CALIPSO lidar measurements, J. Geophys. Res., 113, D16214, doi:10.1029/2007JD009776, 2008a.

Liu, Z., Omar, A., Vaughan, M., Hair, J., and Kittaka, C.: CALIPSO lidar observations of the optical properties of saharan dust: a case study of long-range transport, 113, D07207, doi:10.1029/2007JD008878, 2008b.

Liu, Z., Liu, D., Huang, J., Vaughan, M., Uno, I., Sugimoto, N., Kittaka, C., Trepte, C., Wang, Z., Hostetler, C., and Winker, D.: Airborne dust distributions over the Tibetan Plateau and surrounding areas derived from the first year of CALIPSO lidar observations, Atmos. Chem. Phys., 8, 5045-5060, doi:10.5194/acp-85045-2008, 2008c.

Mahowald, N., Engelstaedter, S., Luo, C., Sealy, A., Artaxo, P., Benitez-Nelson, C., Bonnet, S., Chen, Y., Chuang, P. Y., Cohen, D. D., Dulac, F., Herut, B., Johansen, A. M., Kubilay, N., Losno, R., Maenhaut, W., Paytan, A., Prospero, J. M., Shank, L. M., and Siefert, R. L.: Atmospheric Iron deposition: Global distribution, variability and human perturbations, Ann. Rev. Marine Sci., 1, 245-278, doi:10.1146/annurev.marine.010908.163727, 2009.

Martin, S. T., Andreae, M. O., Artaxo, P., Baumgardner, D., Chen, Q., Goldstein, A. H., Guenther, A., Heald, C. L., Mayol-Bracero, O. L., McMurry, P. H., Pauliquevis, T., Pöschl, U., Prather, K. A., Roberts, G. C., Saleska, S. R., Silva Dias, M. A., Spracklen, D. V., Swietlicki, E., and Trebs, I.: Sources and properties of Amazonian aerosol particles, Rev. Geophys, 48, RG2002, doi:10.1029/2008RG000280, 2010.

Murayama, T., Sugimoto N., Uno I., Kinoshita K., Aoki K., Hagiwara N., Liu Z., Matsui I., Sakai T., Shibata T., Arao K., Sohn B.J., Won J.-G., Yoon S.-C., Li T., Zhou J., Hu H., Abo M., Iokibe K., Koga R., and Iwasaka Y.: Ground-based network observation of Asian dust events of April 1998 in east Asia, J. Geophys. Res., 106(D16), 18346-18359, 2001.

Prenni, A. J., Petters, M. D., Kreidenweis, S. M., Heald, C. L., Martin, S.T., Artaxo, P., Garland, R. M., Wollny, A. G., and Pöschl, U.: Relative roles of biogenic emissions and Saharan dust as ice nuclei in the Amazon Basin, Nat. Geosci., 2, 402-405, 2009. 
Prospero, J. and Carlson, T.: Vertical and areal distribution of Saharan dust over the western equatorial North Atlantic Ocean, J. Geophys. Res., 77, 5255-5265, 1972.

Prospero, J. M., Glaccum, R. A., and Nees, R. T.: Atmospheric transport of soil dust from Africa to South America, Nature, 289, 570-572, 1981.

Prospero, J. M.: Long-term measurements of the transport of African mineral dust to the southeastern United States: Impact on regional air quality, J. Geophys. Res., 104(D13), 15917-15927, 1999.

Prospero, J. M., Ginoux, P., Torres, O., Nicholson, S. E., and Gill, T. E.: Environmental characterization of global sources of atmospheric soil dust identified with the NIMBUS 7 total ozone mapping spectrometer (TOMS) absorbing aerosol product, Rev. Geophys., 40, 1002, doi:10.1029/2000RG000095, 2002.

Quéré, C. L., Raupach, M. R., Canadell, J. G., Marland, G., Bopp, L., Ciais, P., Conway, T. J., Doney, S. C., Feely, R. A., Foster, P., Friedlingstein. P., Gurney, K., Houghton, R. A., House, J. I., Huntingford, C., Levy, P. E., Lomas, M. R., Majkut, J., Metzl, N., Ometto, J. P., Peters, G. P., Prentice, I. C., Randerson, J. T., Running, S. W., Sarmiento, J. L., Schuster, U., Sitch, S., Takahashi, T., Viovy, N., Van der Werf, G. R., and Woodward, F. I.: Trends in the sources and sinks of carbon dioxide, Nat. Geosci., 2, 831-836, 2009.

Ramanathan, V., Crutzen, P. J., Kiehl, J. T., and Rosenfeld, D.: Aerosols, climate, and the hydrological cycle, Science, 294, 2119-2124, 2001.

Reid, J. S., Westphal, D. L., Livingston, J. M., Savoie, D. L., Maring, H. B., Jonsson, H. H., Eleuterio, D. P., Kinney, J. E., and Reid, E. A.: Dust vertical distribution in the Caribbean during the Puerto Rico Dust experiment, Geophys. Res. Lett., 29(7), 1151, doi:10.1029/2001GL014092, 2002.

Rosenfeld, D., Rudich, Y., and Lahav, R.: Desert dust suppressing precipitation - a possible desertification feedback loop, P. Natl. Acad. Sci., 98, 5975-5980, 2001.

Schepanski, K., Tegen, I., Laurent, B., Heinold, B., and Macke, A.: A new Saharan dust source activation frequency map derived from MSG-SEVIRI IR-channels, Geophys. Res. Lett., 34, L18803, doi:10.1029/2007GL030168, 2007.

Schepanski, K., Tegen, I., and Macke, A.: Saharan dust transport and deposition towards the tropical northern Atlantic, Atmos. Chem. Phys., 9, 1173-1189, doi:10.5194/acp-9-1173-2009, 2009.

Smirnov, A., Holben, B. N., Eck, T. F., Dubovik, O., and Slutsker, I.: Effect of wind speed on columnar aerosol optical properties at Midway Island, J. Geophys. Res., 108, 4802, doi:10.1029/2003JD003879, 2003.
Stith, J. L., Ramanathan, V., Cooper, W. A., Roberts, G. C., DeMott, P. J., Carmichael, G., Hatch, C. D., Adhikary, B., Twohy, C. H., and Rogers, D. C.: An overview of aircraft observations from the Pacific Dust Experiment campaign, J, Geophys, Res., 114(d5), D05207, doi:10.1029/2008JD010924, 2009.

Swap, R., Garstang, M., Greco, S., Talbot, R., and Kallberg, P.: Saharan dust in the Amazon Basin, Tellus, 44B, 133-149, 1992.

Talbot, R. W., Andreae, M. O., Berresheim, H., Artaxo, P., Garstang, M., Harriss, R. C., Beecher, K. M., and Li, S. M.: Aerosol chemistry during the wet season in central Amazonia: The influence of long range transport, J. Geophys. Res., 95, 16955-16969, 1990.

Teller, A. and Levin, Z.: The effects of aerosols on precipitation and dimensions of subtropical clouds: a sensitivity study using a numerical cloud model, Atmos. Chem. Phys., 6, 67-80, doi:10.5194/acp-6-67-2006, 2006.

Tesche, M., Ansmann A., Müller, D., Althausen, D., Engelmann, R., Freudenthaler, V., and Groß, S.: Vertically resolved separation of dust and smoke over Cape Verde using multiwavelength Raman and polarization lidars during Saharan Mineral Dust Experiment 2008, J. Geophys. Res., 114, D13202, doi:10.1029/2009JD011862, 2009.

Thomason, L. W., Pitts, M. C., and Winker, D. M.: CALIPSO observations of stratospheric aerosols: a preliminary assessment, Atmos. Chem. Phys., 7, 5283-5290, doi:10.5194/acp-7-52832007, 2007.

Todd, M. C., Washington, R., Martins, J. V., Dubovik, O., Lizcano, G., M'Bainayel, S., and Engelstaedter, S.: Mineral dust emission from the Bode'le' Depression, northern Chad, during BoDEx 2005, J. Geophys. Res., 112, D06207, doi:10.1029/2006JD007170, 2007.

Torres, O., Bhartia, P. K., Herman, J. R., Sinyuk, A., Ginoux, P., and Holben, B.: A long-term record of aerosol optical depth from TOMS observations and comparison to AERONET measurements, J. Atmos. Sci., 59, 398-413, 2002.

Twomey, S.: Pollution and the planetary albedo, Atmos. Environ., 8 1251-1256, 1974.

Vitousek, P. M. and Sanford, R. L. L. Jr.: Nutrient cycling in moist tropical forest, Annu. Rev. Ecol. Syst., 17, 137-167, 1986.

Washington, R. and Todd, M.C.: Atmospheric controls on mineral dust emission from the Bodélé Depression, Chad, Geophys. Res. Lett., 32(17), L17701, doi:10.1029/2005GL023597, 2005.

Yu, H. B., Chin, M., Remer, L. A., Kleidman, R. G., Bellouin, N., Bian, H. S., and Diehl, T.: Variability of marine aerosol finemode fraction and estimates of anthropogenic aerosol component over cloud-free oceans from the Moderate Resolution Imaging Spectroradiometer (MODIS), J. Geophys. Res.-Atmos., 114, D10206, doi:10.1029/2008JD010648, 2009. 